\title{
Integration of Renewable Energy Resources in Microgrid
}

\author{
Manzar Ahmed, Uzma Amin, Suhail Aftab, Zaki Ahmed \\ Electrical Engineering Department, Faculty of Engineering, University of South Asia, Lahore, Pakistan \\ Email: azaki786@usa.edu.pk
}

Received 10 January 2015; accepted 24 January 2015; published 29 January 2015

Copyright (C) 2015 by authors and Scientific Research Publishing Inc.

This work is licensed under the Creative Commons Attribution International License (CC BY).

http://creativecommons.org/licenses/by/4.0/

c) (i) Open Access

\begin{abstract}
Microgrid is a new concept in power generation. The Microgrid concept assumes a cluster of loads and micro sources operating as a single controllable system that provides both power and heat to its local area. Not much is known about Microgrid behavior as a whole system. Some models exist which describe the components of a Microgrid. In this paper, model of Microgrids with steady state and their transient responses to changing inputs are presented. Current models of a fuel cell, microturbines, wind turbine and solar cell have been discussed. Finally a complete model built of Microgrid including the power sources, their power electronics, and a load and mains model in MATLAB/Simulink is presented.
\end{abstract}

\section{Keywords}

Microgrid, Diesel Engine, Fuel Cell, Microturbines, Wind Turbine, Photovoltaic, Genetic Algorithms

\section{Introduction}

The main components of Microgrid are mini-hydro, solar cell, wind energy, fuel cell and energy storage system. These are integrated for electricity generation, energy storage, and a load that normally operates connected to a main grid (macro grid). Microgrid can operate in two modes: one is grid-connected and the other is stand-alone mode. The main benefit of Microgrid is that it can operate in standalone mode or main grid disconnection mode. The Microgrid can then function autonomously. Generation and loads in a Microgrid are usually interconnected at low voltage. But one issue related to Microgrid is that operator should be very vigilant because numbers of power system are connected to Microgrid. In the past, there was single entity to control.

In Microgrid generation resources can include such as fuel cells, wind, solar, or other energy sources as shown in Figure 1. These multiple different electric power supply generation resources have ability to isolate the Microgrid from a large network and will provide highly reliable electric power. Produced heat from gen- 


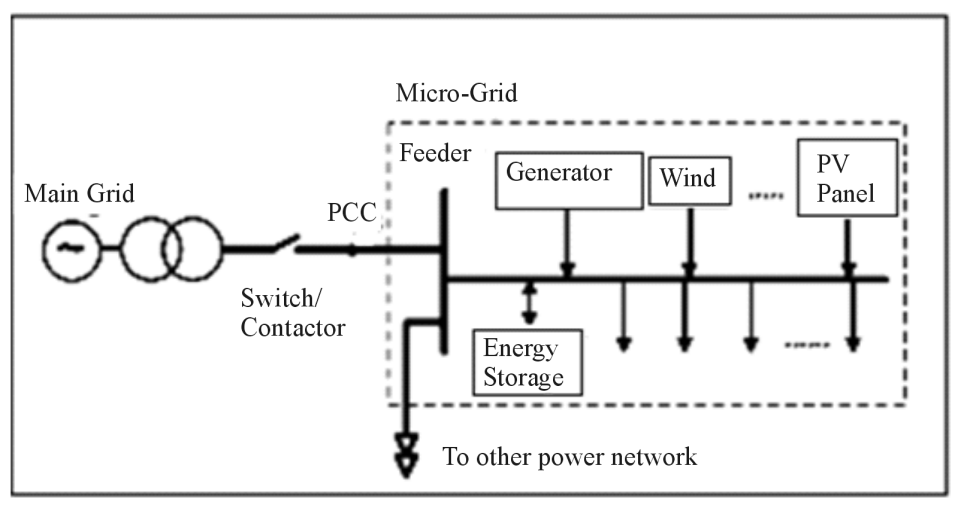

Figure 1. Microgrid systems [1].

eration sources such as microturbines could be used for local process heating or space heating, allowing flexible tradeoff between the needs for heat and electric power.

The followings are parameters of Microgrid:

- Small Microgrid covers 30 - $50 \mathrm{~km}$ radius;

- The small Microgrid can produce power of 5 - 10 MW to serve the customers;

- It is free from huge transmission losses and also free from dependencies on long-distance transmission lines.

\section{DC Microgrid}

The concept of the DC Microgrid closely parallels Thomas Edison's original concept of local DC power generation [1]. This concept could be implemented in $21^{\text {st }}$ century power generation and utilization system. Although the distance between electricity generation sources and loads must be at a minimum, cost-effective solar and wind farms at a particular site also meet the requirements of the DC Microgrid. Minimum conversion from DC to AC and or AC to DC must take place. This increase is partly due to the compatibility of local DC electricity infrastructures, which co-exist with existing electrical infrastructures that are based upon alternating current (AC).

Regarding power storage, DC storage devices such as batteries, capacitors, and fuel cells also meet the requirements of local DC electricity. In essence, the self-sufficient power network of energy generation and energy storage sources, known as the Microgrid is basically a smaller version of the larger power grid. In the absence of no external connectivity of the Microgrid with the main grid is required. This self-sufficient PV-based "Nanogrid" can generate, store and distribute its own power, which is ideally suited for rural electrification.

\section{The Need of DC Local Grid}

Followings are the reasons Microgrid system used in generation of local DC power:

- The traditional model of large base-load AC centralized electrical power generation long haul distribution via high voltage transmission and low-voltage lines causes huge losses of energy and costs required to operate such systems. Direct Current (DC) electricity locally generated by renewable energy sources such as solar panels, windmills used with a minimum conversion (DC to AC or AC to DC) and minimum transmission can reduce energy losses by as much as $30 \%$ or more energy. That is typically lost in AC generation, transmission, and distribution infrastructures.

- Unlike $20^{\text {th }}$ century technologies, the cost of generating local power generated from solar PV and wind systems is decreasing daily, with the substitution of DC for AC power further reducing that cost. Since 2008, solar PV panel prices have fallen well over 70 percent cost of wind turbines decreasing by 40 percent during that same percent. The cost of centralized AC power generation has increased. Wind and solar generated power is cheaper than coal-fired power plants when considering the social costs of carbon foot prints. Some utilities are now using more $\mathrm{PV}$ as it has become more cost effective with the natural gas.

- DC-based PV and wind power systems are more reliable than AC based systems. While the inverter cost is less than about $20 \%$ of PV system cost, any system malfunction can shut the system down, with a total loss in energy production [2]. The Wind energy can be more reliable in DC form because it greatly reduced complexity of the mechanical transmissions system, which is required for wind turbine which generates AC [3]. 
- Batteries, capacitors and fuel cells can be used to store DC electricity. The use of AC in place of DC increases the cost of storage device, as with batteries in which AC based storage systems increase their cost to as much as $50 \%$ [4].

- Integrated circuits and other solid-state devices revolutionized virtually every facet of human life. But a very few of these cases, (e.g. certain motor-based systems), all other loads require DC power, with more of these loads increasingly being DC. For example cathode-ray tube televisions, solid-state TVs do not use AC current. Similarly, though lighting consumes about $20 \%$ of the electricity produced worldwide, it too uses DC power. Also, unlike DC current, typical AC based cell phone chargers waste approximately $20 \%$ - 35\% energy used [5]. Electrical vehicles do not require AC power for charging batteries. With revolution in the IT industry, more semiconductor based electronics are being used, with a concurrent increase in DC loads and a decrease in AC loads.

- The battery-based hybrid and electrical vehicles and solid-state based LED lighting are transforming the transportation and lighting industries, both of which are powered by direct current.

- Energy-efficient appliances use adjustable speed motor drives in which a rectifier converters the AC from the grid into an internal DC bus voltage.

- A DC Microgrid is the key enabler of the "zero energy building model". With minimum wastage in transmission and conversion, the use of locally generated DC electricity can provide $100 \%$ energy needs of a building.

- The worldwide adoption of DC power can prevent such a redundancy of efforts by providing uniform voltage standards worldwide, thus reducing the cost of related power electronics to yield an overall lower manufacturing cost of every DC-based electrical system. Local DC electricity as affordable electricity to underprivileged people in worldwide 2.6 billion people in the developing countries depend on bio fuel energy (fuel from wood, charcoal, and animal dung) to meet their energy needs for cooking and other daily necessities.

The worldwide adoption of DC power can prevent such a redundancy of effort by provide uniform voltage standards worldwide, thus reducing the cost of related power electronics to yield an overall lower manufacturing cost of every DC-based electrical system. The Microgrid architecture is shown in Figure 2.

\section{AC and DC Transmission System}

In past we are using AC transmission system and it become now mature system. The output of an AC transmission line is directly proportional to the square of the voltage and inversely proportional to the impedance of the transmission line. But it depends on the distance between load and line. Losses increases with distance. To attain high level transmission capability in long distance transmission line AC lines, a simple way is increase the voltage level. For small-to-medium scale RE power supply transmission lines below $330 \mathrm{kV}$ are usually used. For large scale, long-distance RE power, transmission lines above $500 \mathrm{kV}$ are usually needed. An example of AC transmission above $500 \mathrm{kV}$ for RE integration is given below. For transmission \& distribution, major AC/DC grids will be interconnected and the consumer will combine consumption and production of energy. Grid design will evolve to a network of interconnected small and large grids shown in Table 1.

\section{Power Generation \& Storage Issues}

Followings are the related power generation system and energy storage issues with related dc system:

- Maintaining grid reliability requires precise synchronization of voltage and current. The ratio of actual power to theoretical power is the "power factor", and typically runs between $85 \%$ - 95\%. As power factor falls, generators still make the same amount of power and burn the same amount of fuel, but less gets to the load, so the effect is to lower system-wide fuel efficiency.

- Motors, capacitors, and other electrical devices cause current to shift out of phase with voltage, so power factor degradation is unavoidable and grid operator must take actions to correct.

- Location is always play important role while calculating losses. The resistance of a wire is directly related to the length of the wire. Voltage is directly proportional to the resistance and current. When more wire used to separate a generator and the load, it greater current and therefore greater energy losses through that wire for any given voltage. These line losses typically run $3 \%-6 \%$ on average but increase rapidly during peak hours when wires are congested and often exceed up to $25 \%$. 


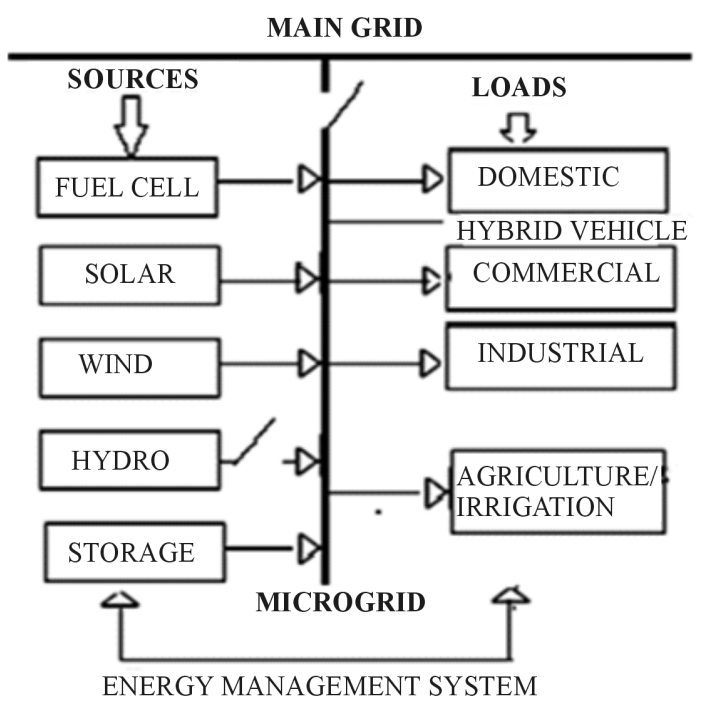

Figure 2. Architecture of Microgrid.

Table 1. Microgrid components.

\begin{tabular}{|c|c|}
\hline Power Generation System & Storage issues \\
\hline $\begin{array}{l}\text { Resources, devices, machine, } \\
\text { electrical control }\end{array}$ & $\begin{array}{l}\text { - Medium size and micro-turbines } \\
\text { - Permanent magnet and doubly fed induction generators } \\
\text { - Efficient inverters } \\
\text { - Self-excited induction generators } \\
\text { - Asynchronous or synchronous generators } \\
\text { - Induction machine and DC machine based storage system such as flywheels }\end{array}$ \\
\hline $\begin{array}{l}\text { Advanced electrical design of } \\
\text { devices and components }\end{array}$ & $\begin{array}{l}\text { - Dynamic design of wind turbines } \\
\text { - Bio-fuel based turbines } \\
\text { - PV Solar cell system with high insulation system and sun tracking system to get maximum power } \\
\text { - Minimum looses smooth output of wind farms }\end{array}$ \\
\hline Types of loads & $\begin{array}{l}\text { - Dynamic modeling of loads } \\
\text { - Adoptive and frequency/voltage dependent characteristics of loads } \\
\text { - Real time load shedding planning } \\
\text { - Adoptive load management } \\
\text { - SCADA based control }\end{array}$ \\
\hline Energy management methods & $\begin{array}{l}\text { - Both systems adoptable either centralized vs. decentralized control system. } \\
\text { - Impedance matching to control reactive power and minimizing losses } \\
\text { - Efficient protection methods } \\
\text { - Implementation of hybrid sources to control fault current levels in the micro-grid } \\
\text { - Smooth coordination with other micro-grid with the conventional grid } \\
\text { - Intelligent Interface system } \\
\text { - Operate in both modes grid connected or Islanding and detection methodologies } \\
\text { - Low-voltage controlling system }\end{array}$ \\
\hline
\end{tabular}

\section{Methodology}

Following steps are proposed for implementation of Microgrid system:

- First we need to select electric power supply system such as renewable energy resources according to requirement and availability of input source;

- Then we need to integrate all these resources in Microgrid such as renewable energy resources;

- Energy storage and Management system;

- Integration of renewable energy in Microgrid;

- Energy control and management in Microgrid. 


\section{The Proposed Model}

Figure 3 shows the proposed model for Microgrid system. The inputs of the system are renewable energies such as solar energy, wind energy, hydro and fuel cell energy. After minimizing the losses and increase the efficiencies of the systems the energies can be combined standard are applied on the energy input and finally stored energy can be integrated into grid.

\subsection{Selection of Renewable Energy Resources}

The most important step is to select the types of renewable energy resources because it depends on the location and environment. In this research work three renewable energy systems are considered such as solar, wind and fuel cell. The advantages of selected system are given in Table 2. For all these systems we need efficient energy storage and monitoring system. With revolution in the IT industry, more semiconductor based electronics are being used, with a concurrent increase in DC loads and a decrease in AC loads.

\subsection{Energy Storage and Management in Microgrid}

There are following reasons for energy storage:

- Smart grid;

- Increasing use of demand response;

- Commonly available electricity price signals;

- Regulatory incentives;

- Transmission capacity constraints;

- Increasing usage of electric vehicles;

- Increasing usage of renewable energy sources;

- Distributed energy sources;

- Environmental concerns due to fossil-based fuel use;

- Advancements in storage technology.

\subsection{Integration of Renewable System in Microgrid}

Distributed generation can support weak grids, adding grid voltage and improving power quality. In certain circumstances, distributed generation can be used in conjunction with capacitor banks for management of power flows or to manage active and reactive power balance. In Figure 4 the proposed method of integration of energy in girds is shown. In the block diagram all the resources such as wind turbine energy, solar energy (PV), Fuel cell and hydro is integrated in the main grid (IG). The output of fuel cell hydrogen $\left(\mathrm{H}_{2}\right)$ is provided to the vehicles for transportation as a fuel. If harvested and taken care of control system, it can reduce environmental impacts such as:

- Can reduced emission of green house gases hazard for environment;

- Can reduced dependencies on local or imported fuels and increased energy security due to distribution generation and share of all energy sources.

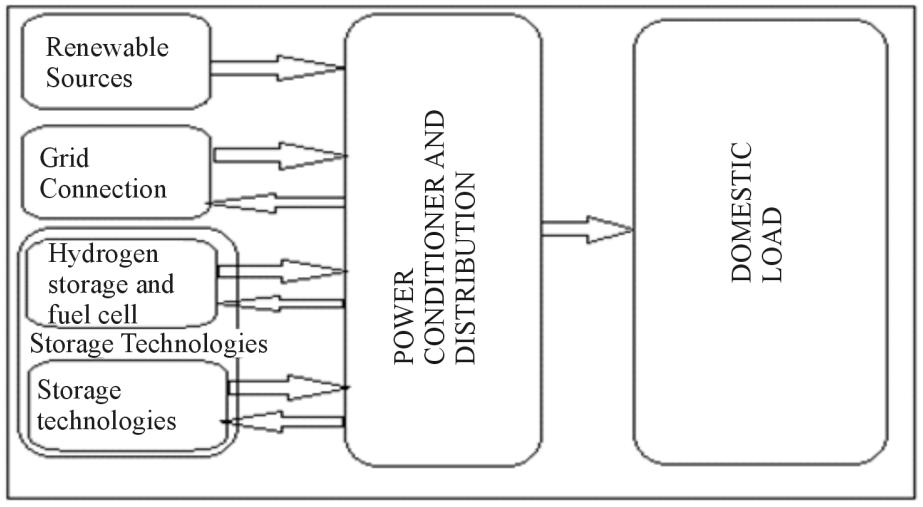

Figure 3. Proposed Microgrid distribution system. 
Table 2. System components.

\begin{tabular}{|c|c|}
\hline Main Sources & Macro Grid Generators \\
\hline Renewable Energy Resources & $\begin{array}{l}\text { - Small hydro system } \\
\text { - Wind energy } \\
\text { - Bio fuel energy } \\
\text { - PV solar cell } \\
\text { - Ocean energy and geothermal energy }\end{array}$ \\
\hline Energy Storage Systems & $\begin{array}{l}\text { - Fuel cells (PEM, SOFC and alkaline) } \\
\text { - Batteries (lithium) } \\
\text { - Super capacitor } \\
\text { - Pump storage } \\
\text { - Fly wheel }\end{array}$ \\
\hline Types of Loads & $\begin{array}{l}\text { - Small (domestic) } \\
\text { - Medium (commercial) } \\
\text { - Large (agriculture/irrigation three phase) and industrial-three phase }\end{array}$ \\
\hline Technical Parameters & $\begin{array}{l}\text { - Preferably linear } \\
\text { - Balanced line not unbalanced } \\
\text { - System should be dynamic }\end{array}$ \\
\hline
\end{tabular}

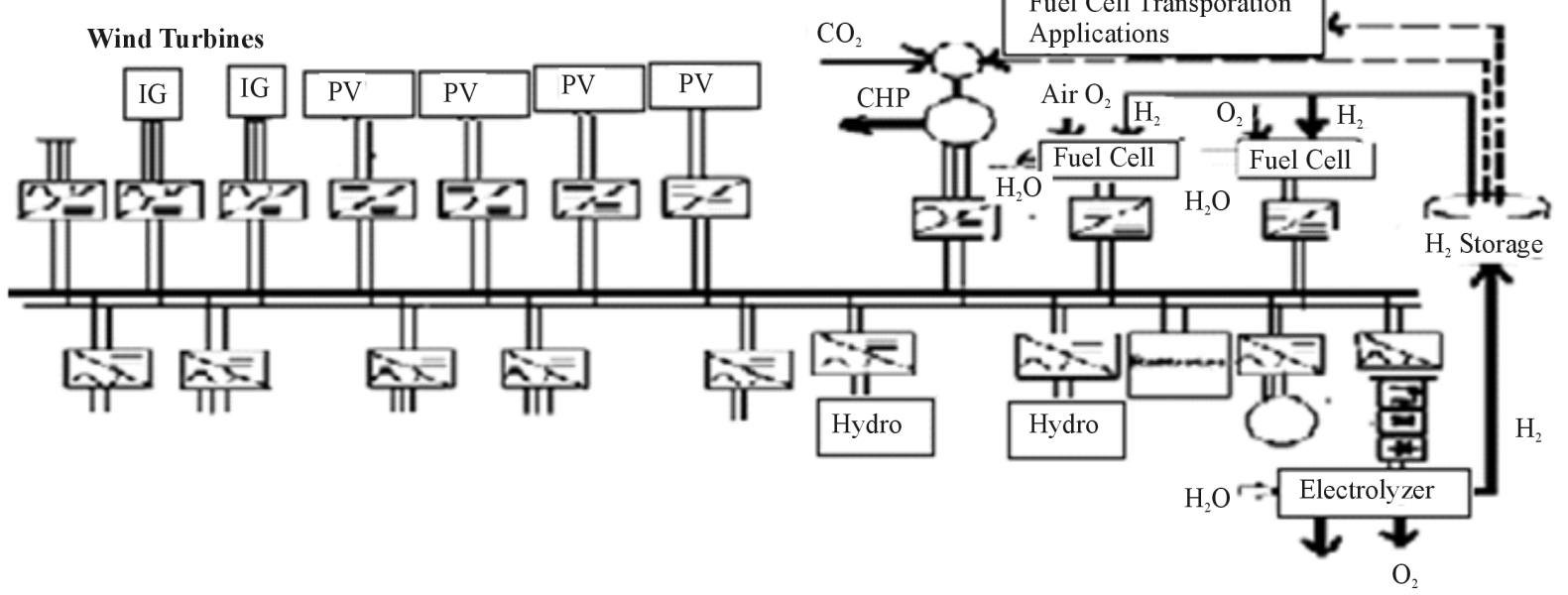

Figure 4. Integration of energy resources.

\subsection{Proposed Modes of Operation}

In future each home would have its own uninterruptible renewable energy system and has the capability to work in two main modes of operation such grid-connected mode and stand-alone mode. This system will be capable of producing a smooth, uninterrupted transition between these modes by using an advanced islanding detection and resynchronization algorithm. The both mode of transition power cycle is shown in the Figure 5. There are two modes of operations as shown in figure below, stand alone and grid connected. When the power is shut off from the utility grid the system goes to the islanding mode and when the power is available from the utility grid the system will synchronize and connected to the utility grid. Output power from the fuel cell is available for Plug in hybrid electric vehicles (PHEV) system. Bidirectional Power Converter (BPC) controls two parameters active current and active/reactive power. In standalone mode BPC control two parameters AC frequency and voltage.

The following paragraph will provide working principle of these modes. There are always changes in the condition of weather and speed of wind. Wind and solar system are condition dependents. These systems should be adoptable. This means that these systems should change operating parameters according to the changes in weather conditions. These parameters are very unpredictable. These parameters cannot be predicted even the operators in the grid cannot predict the speed of wind and sun light conditions for solar cell farms accurately. The output of these systems still always varies and operator needs to be very careful in the grid. Still there are lots of issues not to solve. 


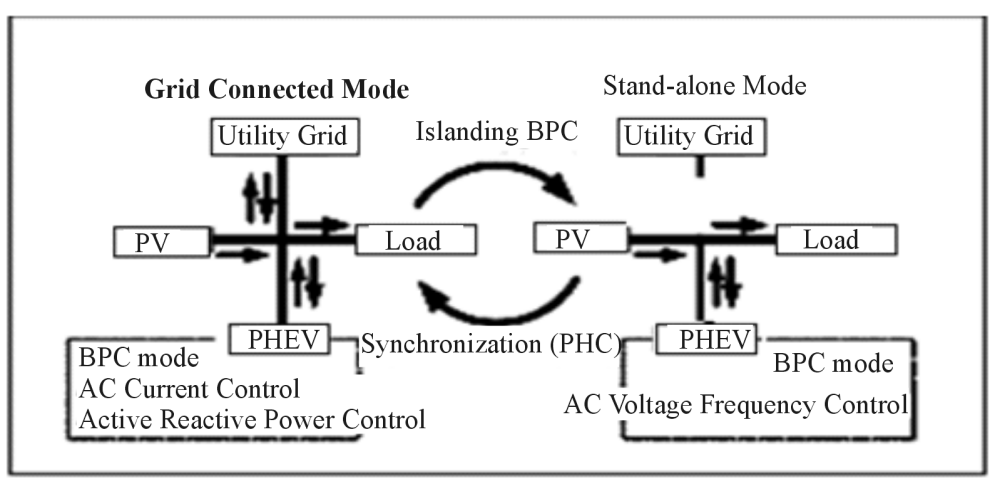

Figure 5. Mode of operation.

In grid control of voltage and frequency are very necessary because in seconds to minutes time scale the grid operators must know how to deal with fluctuations in frequency and voltage on the transmission in transmission line system. From these parameters if anyone left unchecked it could damage the system as well as equipment used in the grid. In that case operator may need to start generators to insert power (may be active or reactive) into the Microgrid but this power is free of cost not for sale to consumers but it used in order to balance the actual and predicted forecasted generation of electrical power which is necessary to minimize the variation in frequency and voltage on the grid. These necessary services must be provided by the grid when required.

Typical services are:

- Variation in the frequency occurs rapidly and must be control. These variations can control by using device Automatic generation control (AGC) signals to grid generators;

- Some generator must be in the reserve when fault occurs in the main generators reserve generators should provide power within 10 minutes. These reserves generators are used when main generator on the system become faulty or deactivates from the system unexpectedly;

- Some generators run in the same way as reserve generators but they have same function but may have a slower response time;

- When voltage goes down in main grid the generators used for reactive power to boost up the voltage to desire level when required in grid;

- In Microgrid generators should be available to restart the power system if the load shading persists for long time.

\section{Power Management System}

In Microgrid system all energy recourses can be control such as renewable resources and also control changes in the grid's operating conditions. It can provide additional benefits because it is distributed generation system or when installed at the transmission level. The power management system is shown Figure 6. In below diagram there are three main parts of the system, distributed generation (DG), Microgrid and Loads and storage. Main components of loads and storage are variable speed drives (HVAC, heat pumps), lighting control and battery storage for electrical vehicles (EV).

Key components in the Microgrid are:

- Smart metering, which enables two-way communication between utilities and customers (including electrical energy storage facilities such as rechargeable batteries and electric vehicles) or dispersed generation (DG) [6];

- Information technologies, which enable optimal control of the total grid even where very many DG units are integrated;

- Energy management systems, which implement the most efficient possible use of electrical energy for customers;

- Advanced control and protection systems, which improve the security and reliability of both small- and large-scale power networks [7];

- The technologies for Microgrid have mainly been debated in the context of optimization of small power networks. 


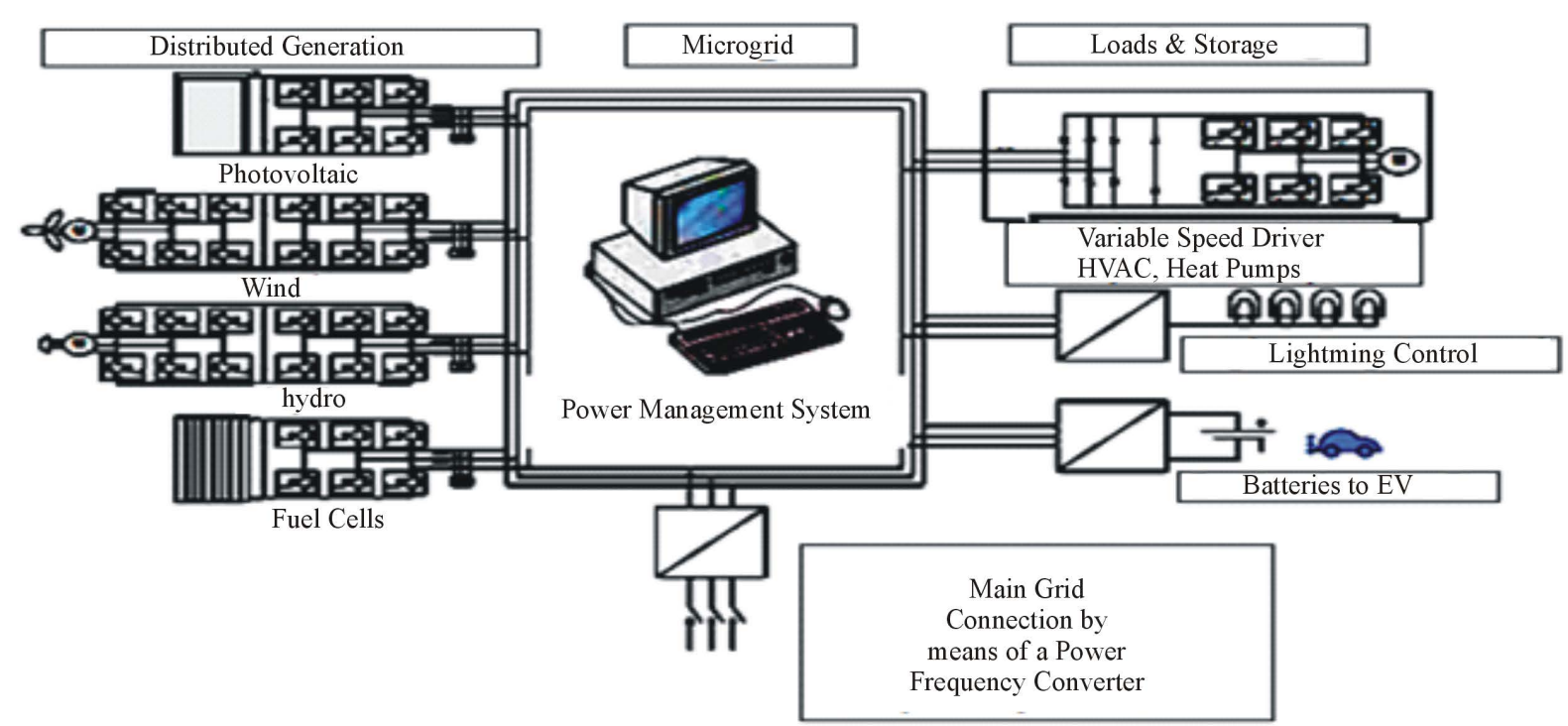

Figure 6. Complete circuit of green energy integration.

\section{Implementation of Distribution System}

- In future to provide clean environment we must reduce $\mathrm{CO}_{2}$. One way is to reduce it by using it in other system and convert it to another form. In micro grid the preferred system is decentralizing system. By decentralizing the micro grid the system the system efficiency would be increased and hence reduce the amount of electrical energy lost in transmission system. The transmission lines may be reduced by increasing the efficiency of the power system and this will be more economically beneficiary to reduce number of power lines that will need to be installed in the future to fulfill the demand. CHP system will play very important role in micro grid system. CHP Power and heat in micro grid system could provide additional benefits and will increase efficiency by up to $85 \%$ - $95 \%$. This would be significant increase in Grid system the current fossil fuel system only have an efficiency of 34\% [8].

- Green energy system must be implemented to satisfy the customers those customers who are not satisfied with the local electric supply system they can approach to green energy via the electrical power grid or they can install their own energy system such as renewable energy system. The consumer who are not satisfy can install their own electric power supply system such as mini-hydro, fuel cell, PV solar cell and wind turbines and many other types of renewable energy systems which are available in countries. In future Pakistan must install Microgrid system for green, clean and pollution free environment.

\section{Mathematical Modeling}

The following equation used for calculation of active reactive power and harmonics.

$$
\begin{gathered}
Y U=P+J Q \\
U_{K} \in\left\{U_{k, 1}, \cdots \cdots, U_{k, m}\right\},\left|I_{k}\right| \leq I^{\max }
\end{gathered}
$$

For $k \in$ Step-down

$$
\begin{gathered}
U_{i}^{\min } \leq\left|U_{i}\right| \geq U_{i}^{\max },\left|I_{i, k}\right| \geq I_{i}^{\max } \\
P_{i}^{\min } \leq P_{i}\left(U ; \pi_{i}\right) \leq P_{i}^{\max } \\
Q_{i}^{\min } \leq Q_{i} \leq\left(U_{i} ; \mu_{i}\right) \leq Q_{i}^{\max }
\end{gathered}
$$

For the selected area value of $\Delta U$ selected as $\Delta U \geq 4 \%$ 


$$
\begin{aligned}
& \Delta U \geq 3 \% \\
& \Delta U \geq 2 \% \\
& \Delta U<2 \% \text { (at main point) }
\end{aligned}
$$

\section{Simulink Model for Microgrid}

In Microgrids all renewable energies are integrated in DC system and stored in grid. Both AC and DC bus can be used. Proposed system block diagram is shown in Figure 7. For the load profile new elements like PV, E-car, batteries, fuel cells, wind etc can be used.

For simulation methods, load profile simulation used for domestic load. Unbalanced dynamics protection/ restoration strategies used for in proposed model. The Simulink model used in this research work is shown in Figure 8. In Simulink model as shown in figure the number of load points are 16 and power sources used in this model are fuel cell (FC), wind turbines and photovoltaic cells in Microgrid. For the simulation purpose the solar cells power is used with main hydro power.

The active power supply remains constant, independent of the voltage. If this is above or below predefined voltage limits, the DC-In feeder is removed from the network. The reactive power demand for the inverter is simulated by a factor for the required reactive power. Photovoltaic in feeders behave the same way in any procedure based on load flow.

Short Circuit-Maximum: the current supply is constant and calculated from the installed peak power.

Short Circuit-Minimum: this method ignores DC-In feeders.

Short Circuit-Standard: the current supply is constant and calculated from the installed peak power and the current factor for active power. In all the procedures based on short circuit (multiple fault, protection, etc.), photovoltaic supply behaves in the same way.

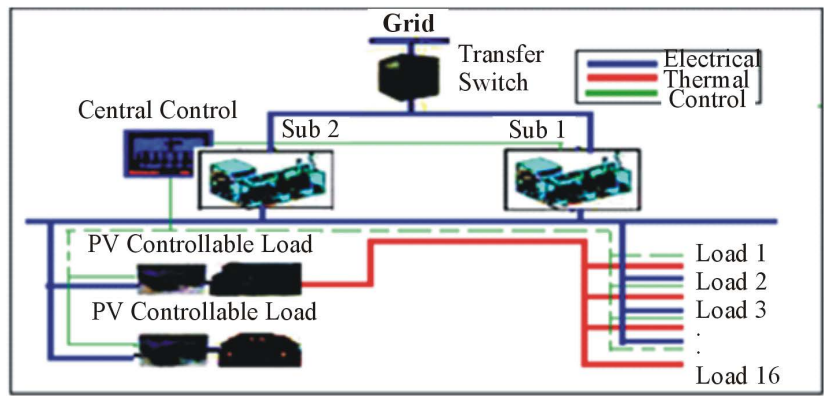

Figure 7. Blocked diagram of proposed system.

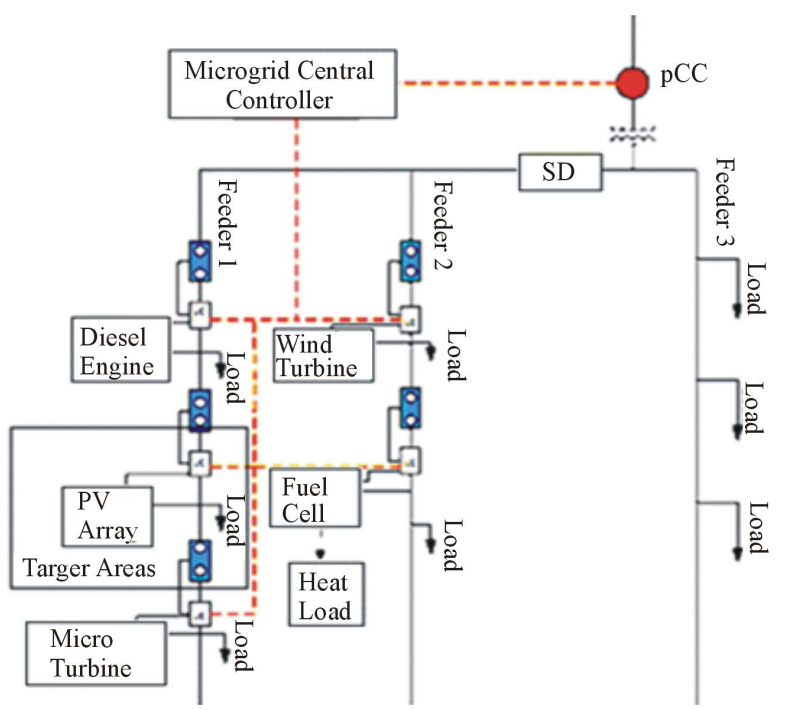

Figure 8. Microgrid Simulink model. 


\subsection{Smart Generation}

- Distributed generation like PV cell, E-cars, batteries, fuel cells, wind, etc.;

- Virtual power plants;

- Decentralized energy management.

\subsection{Load Profile Simulation}

- Smart metering - Meter reading + Active meter controlling;

- Load management;

- Cost models.

For simulation the total power is $89.76 \mathrm{KW}$ to $255 \mathrm{KW}$ for PV Load efficiency 30\% to 100\% selected for area. Single line diagram with $30 \%$ to $100 \%$ load efficiency is shown in Figure 9, Figure 11, Figure 13, Figure 15, Figure 17, Figure 19, Figure 21 and Figure 23 respectively. The total load is distributed among the eight domestic loads. The curve shows the covered area and total distribution in smart grid. Load efficiency graphs with 30\% to 100\% Photovoltaic efficiency shown in Figure 10, Figure 12, Figure 14, Figure 16, Figure 18, Figure 20, Figure 22 and Figure 24 respectively. It can be concluded from graphs that power decreases increasing covered area.

It can be concluded that as the load efficiency of the PV cells increase the distribution curve limited to support loads. It can be seen at 30\% load efficiency it covered maximum area as the efficiency increased to $112 \%$ in Microgrid the curve limited to wide area. Eight points of loads were selected. In future all alternative energy resources can be applied in Microgrid using same method.

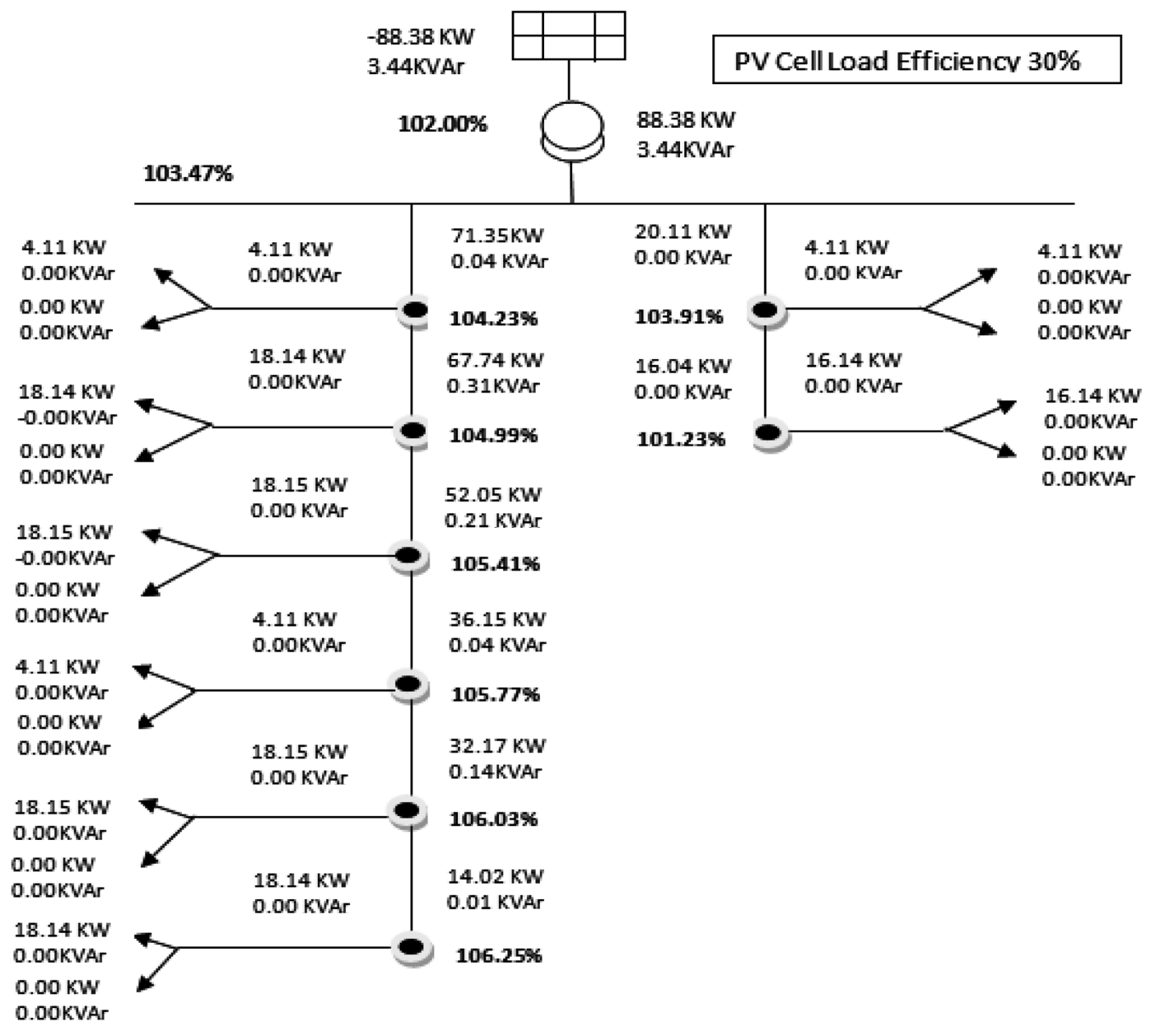

Figure 9. Single line diagram with 30\% load efficiency. 
U/Un [\%]

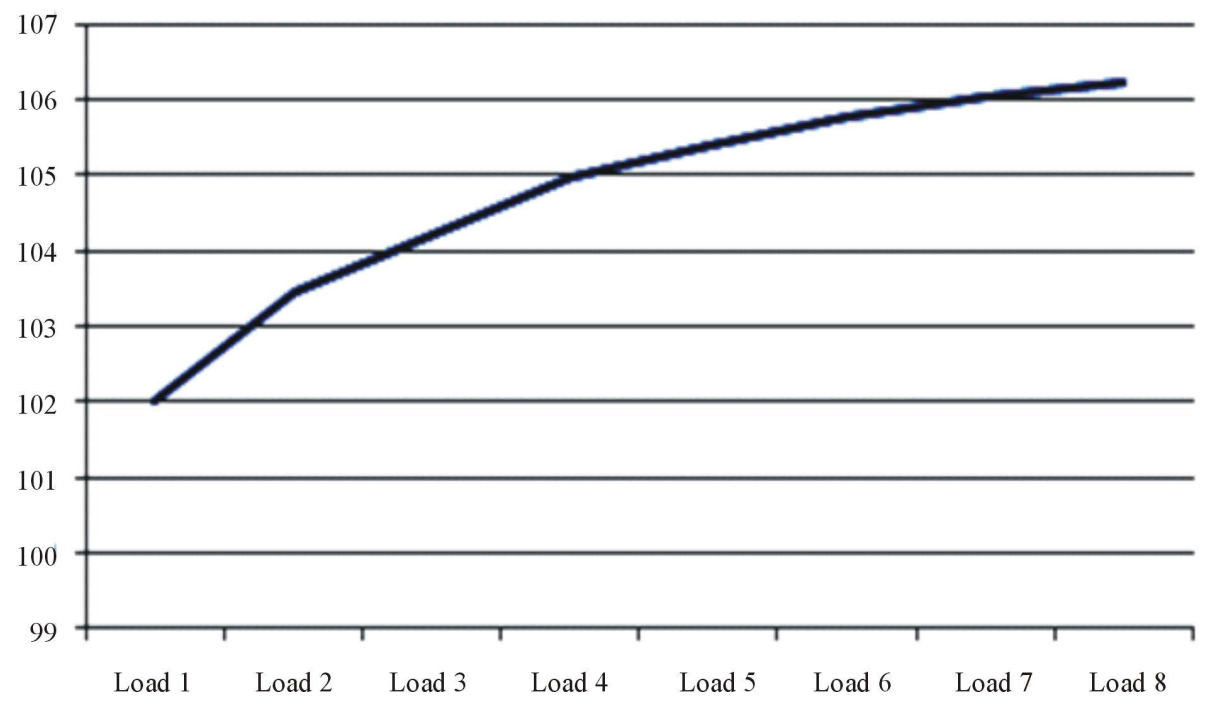

Figure 10. Loads efficiency with 30\% PV efficiency.

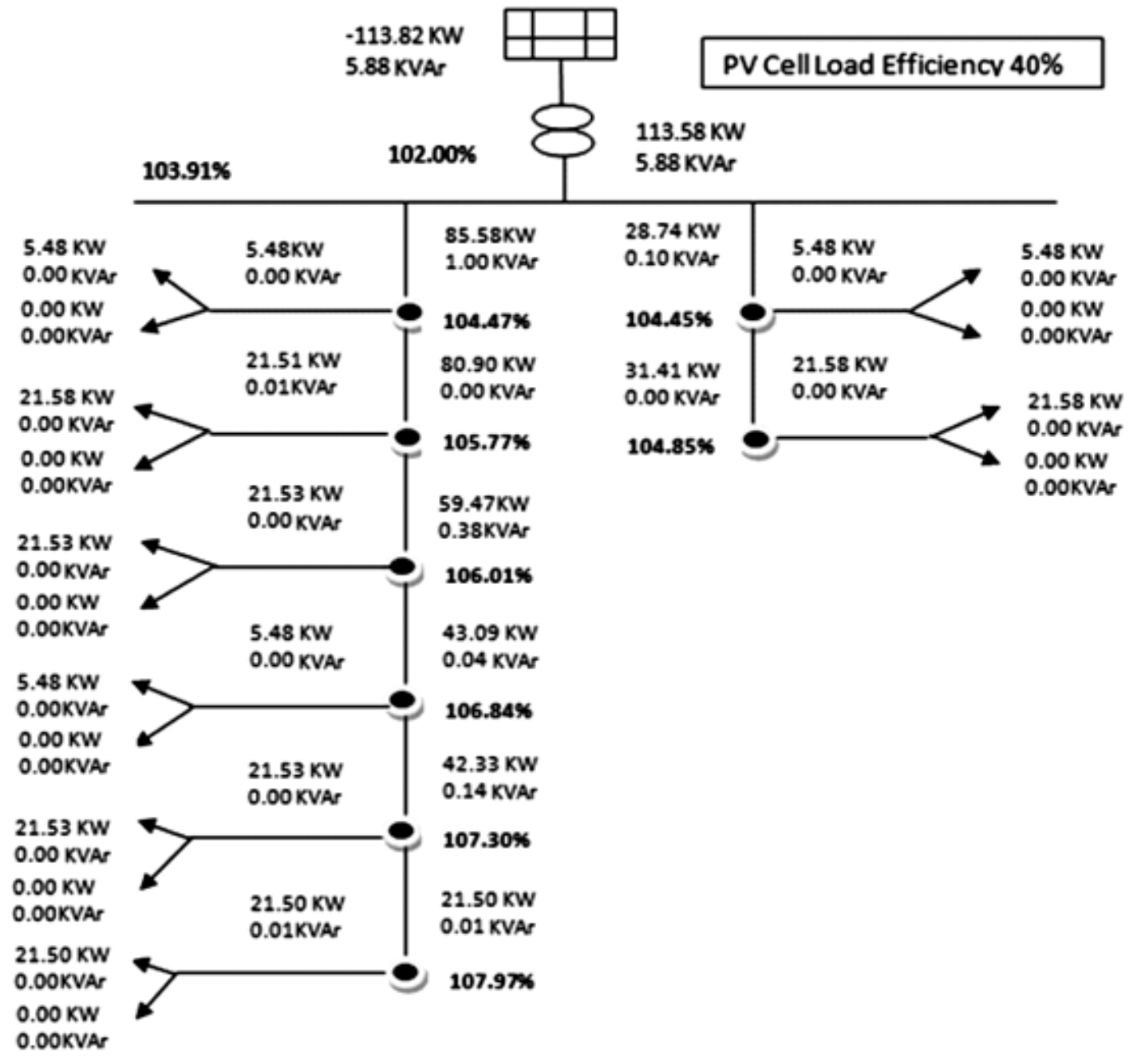

Figure 11. Single line diagram with $40 \%$ load efficiency. 
$\mathrm{U} / \mathrm{Un}[\%]$

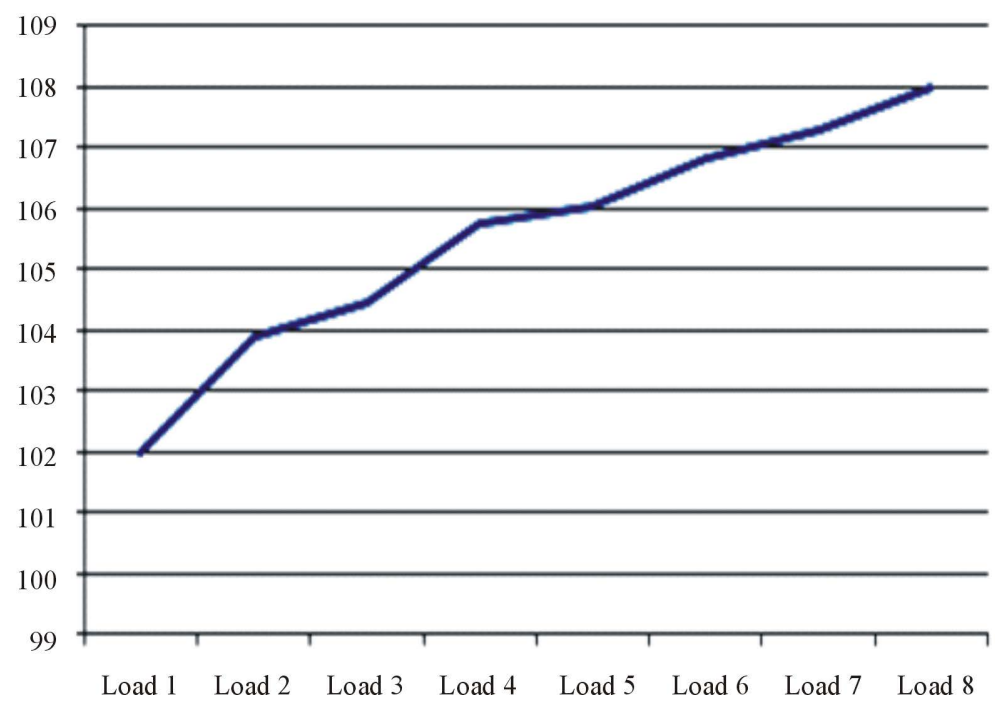

Figure 12. Loads efficiency with 40\% PV efficiency.

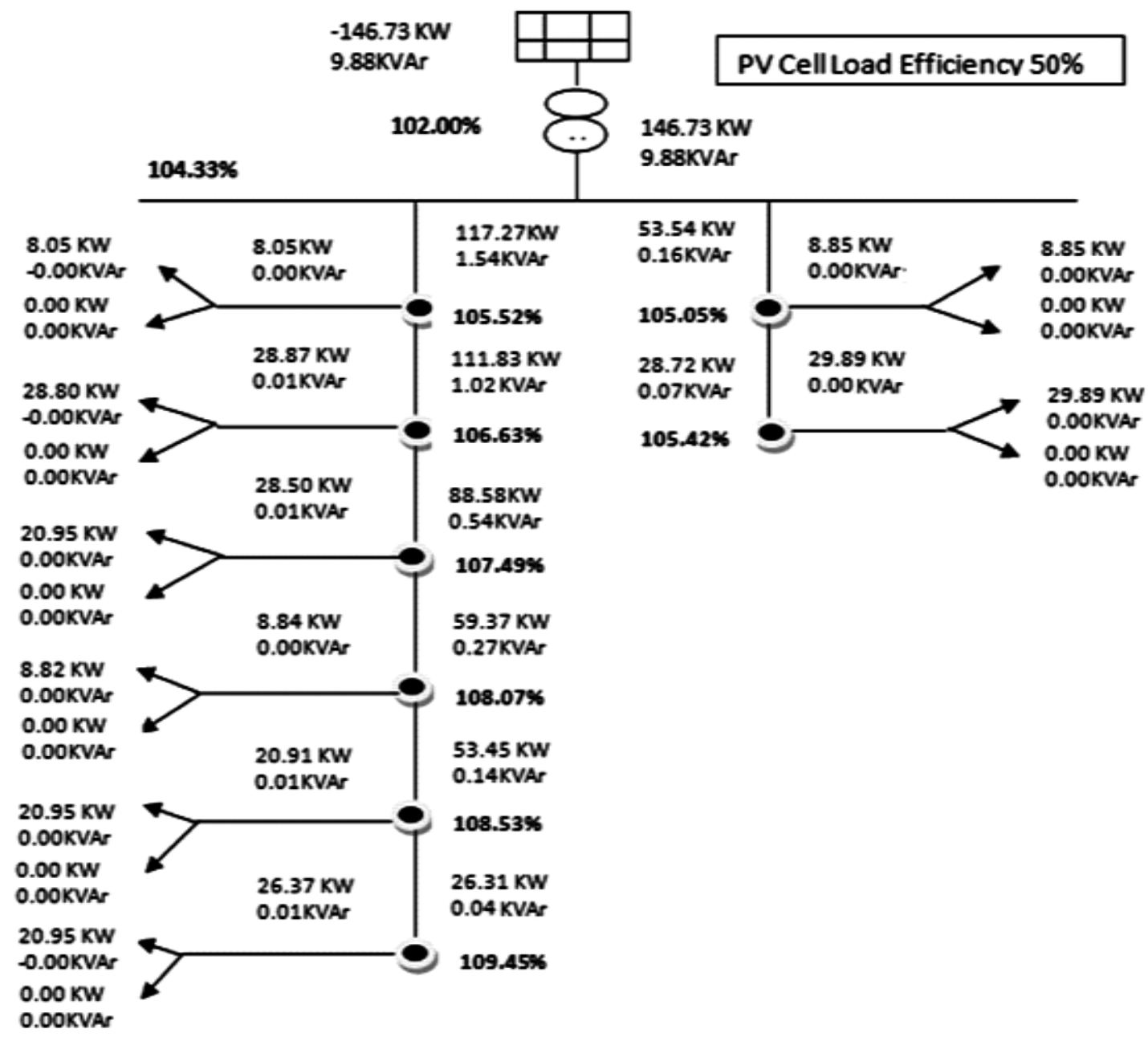

Figure 13. Single line diagram with $50 \%$ load efficiency. 
U/Un [\%]

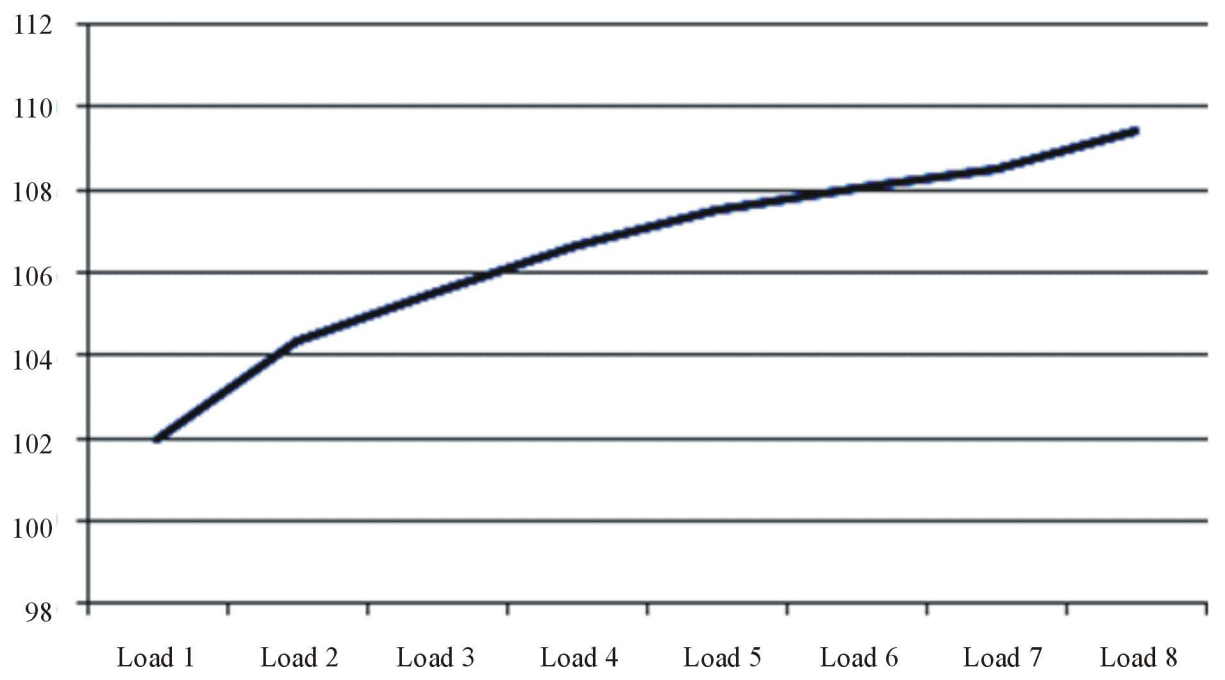

Figure 14. Loads efficiency with 50\% PV efficiency.

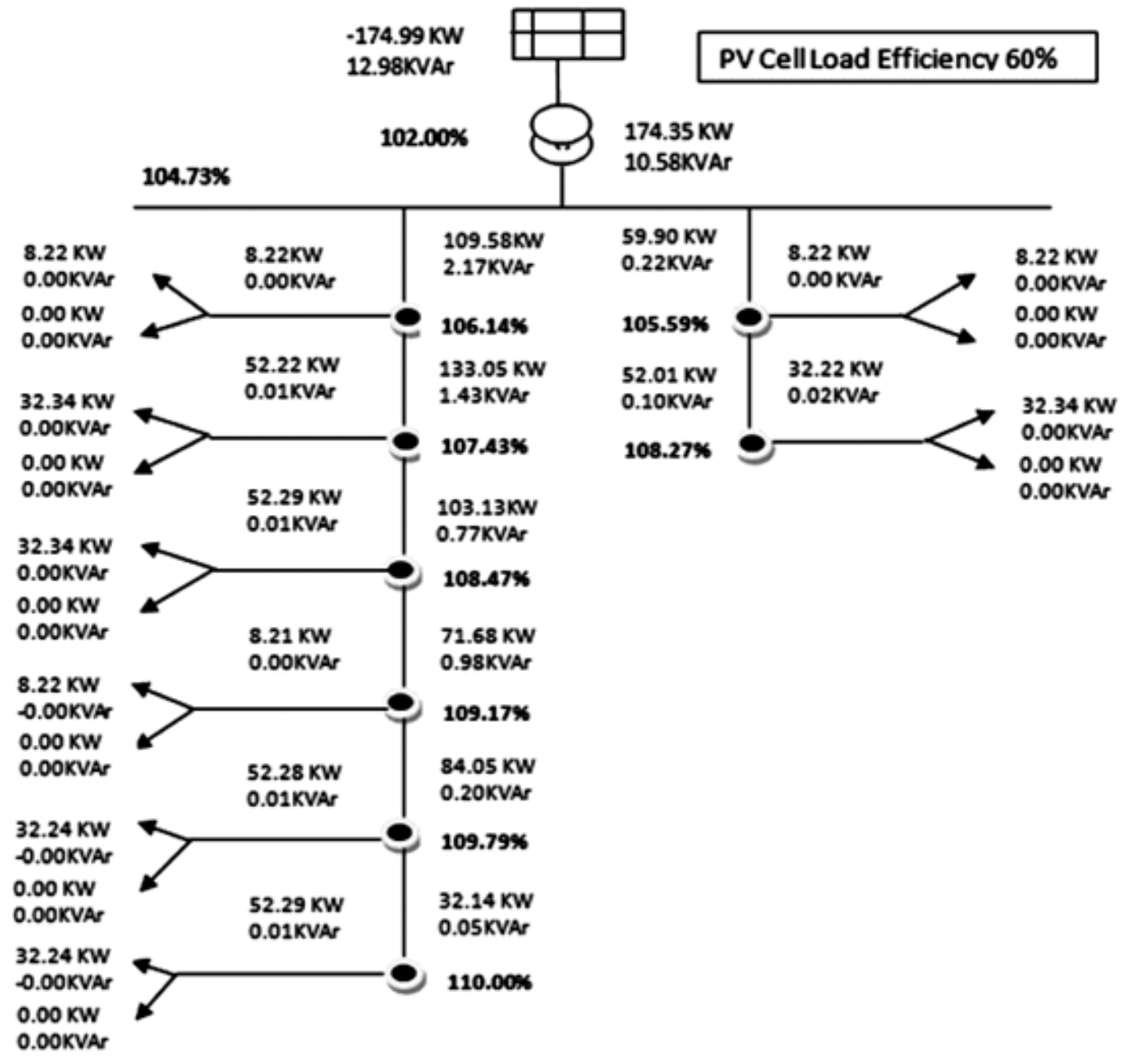

Figure 15. Single line diagram with $60 \%$ load efficiency. 
U/Un [\%]

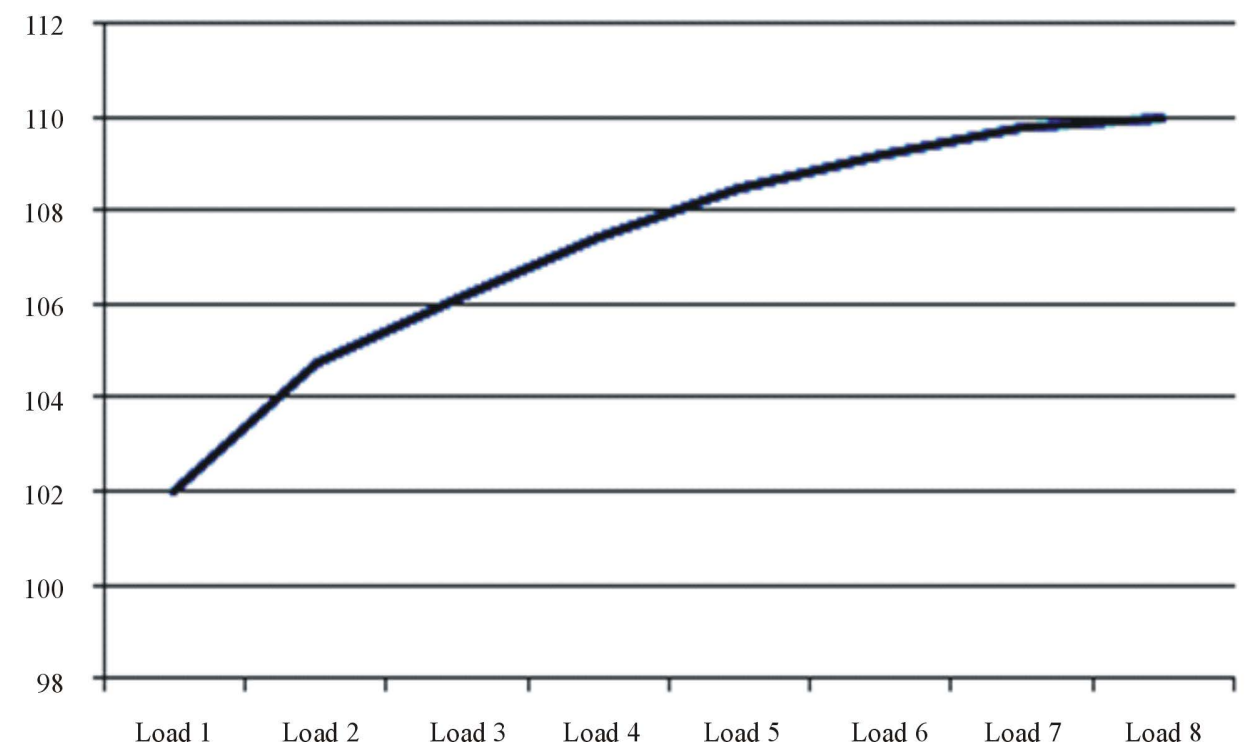

Figure 16. Loads efficiency with 60\% PV efficiency.

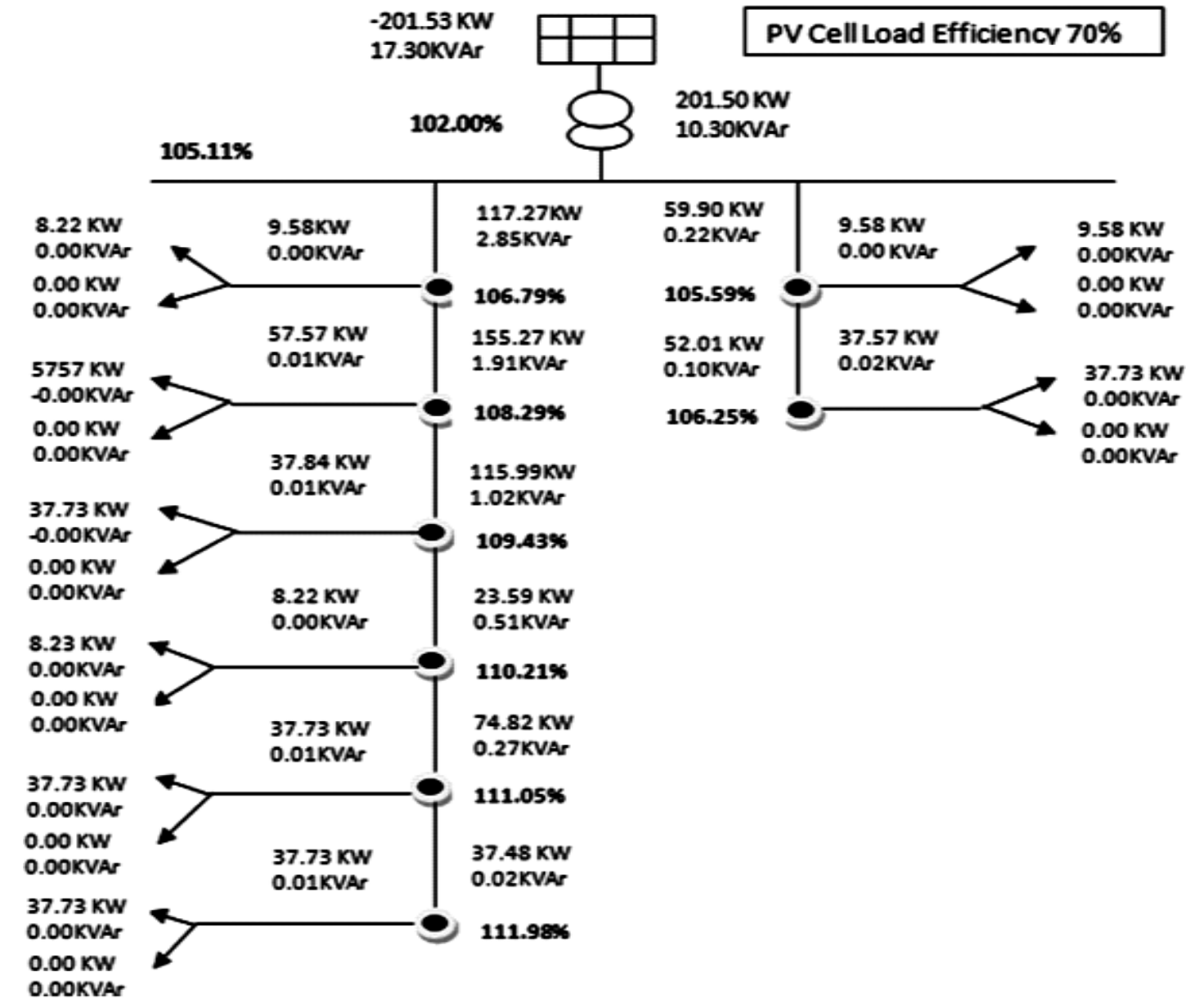

Figure 17. Single line diagram with $70 \%$ load efficiency. 
U/Un [\%]

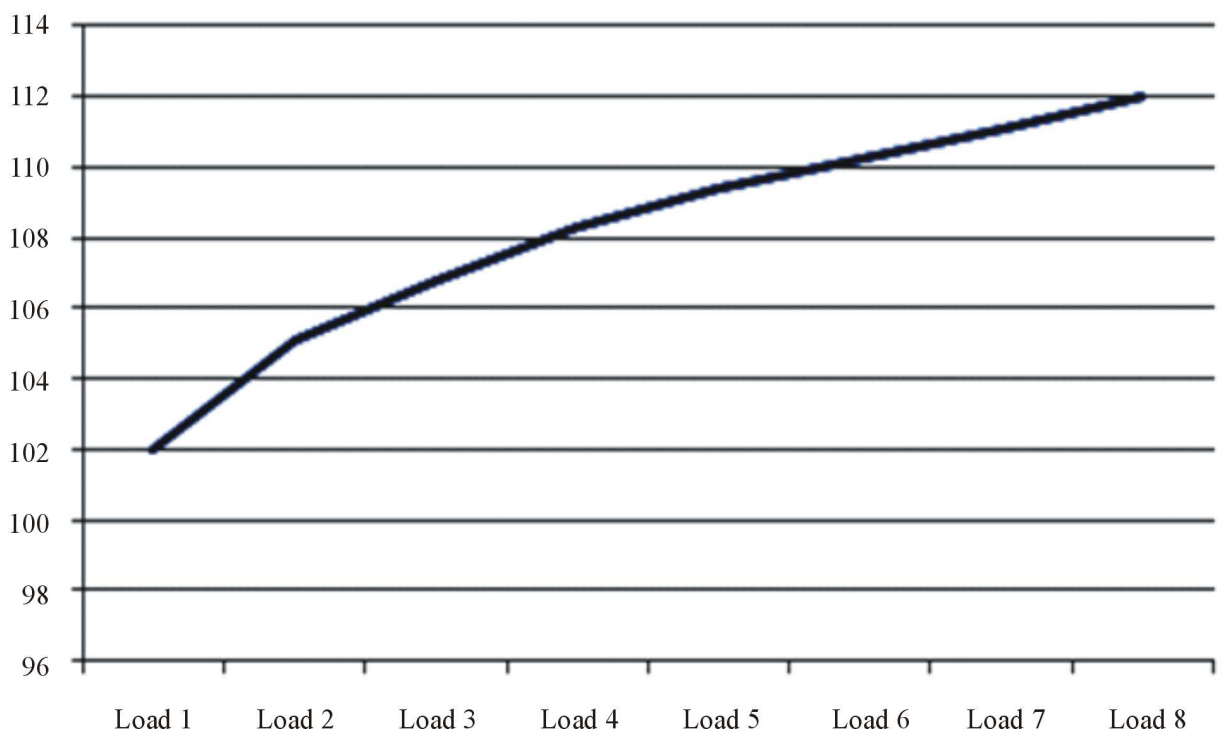

Figure 18. Loads efficiency with 70\% PV efficiency.

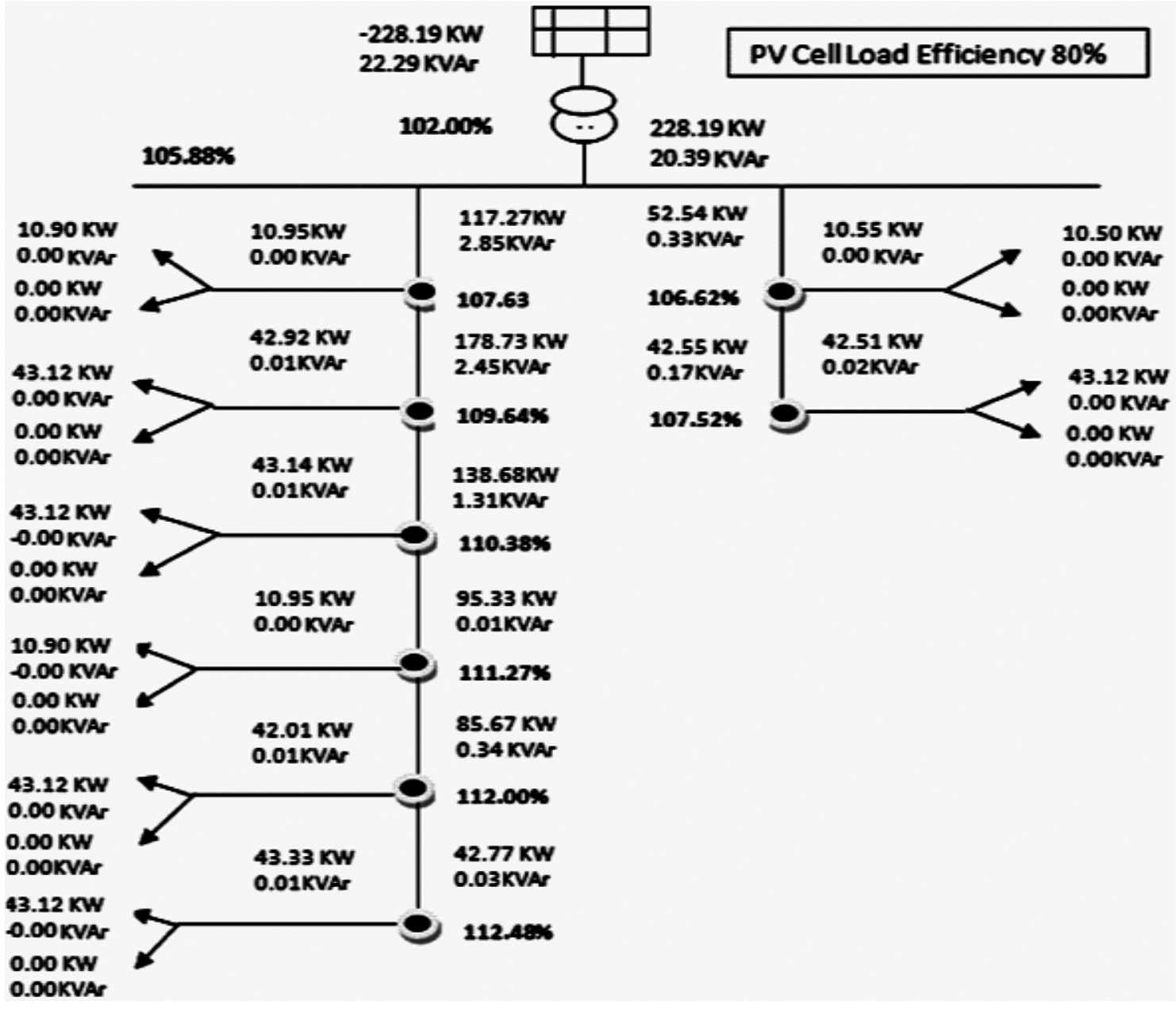

Figure 19. Single line diagram with $80 \%$ load efficiency. 


\section{U/Un [\%]}

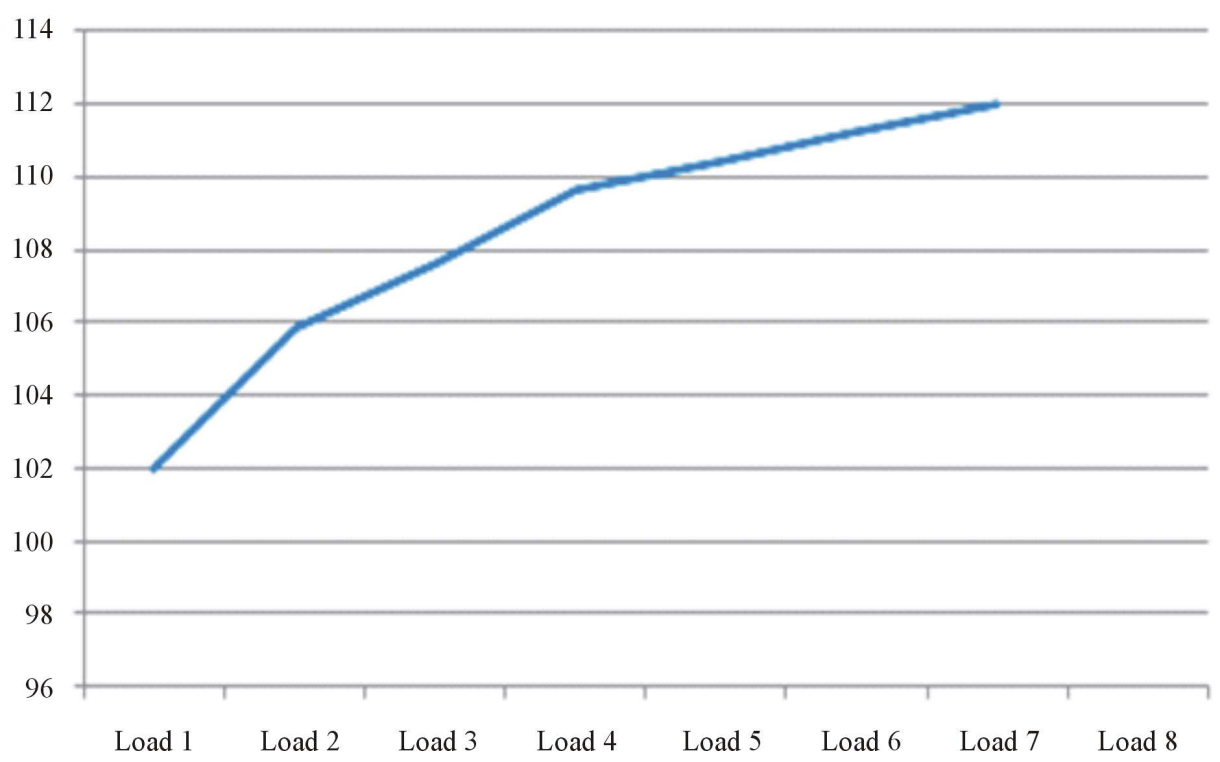

Figure 20. Loads efficiency with $80 \%$ PV efficiency.

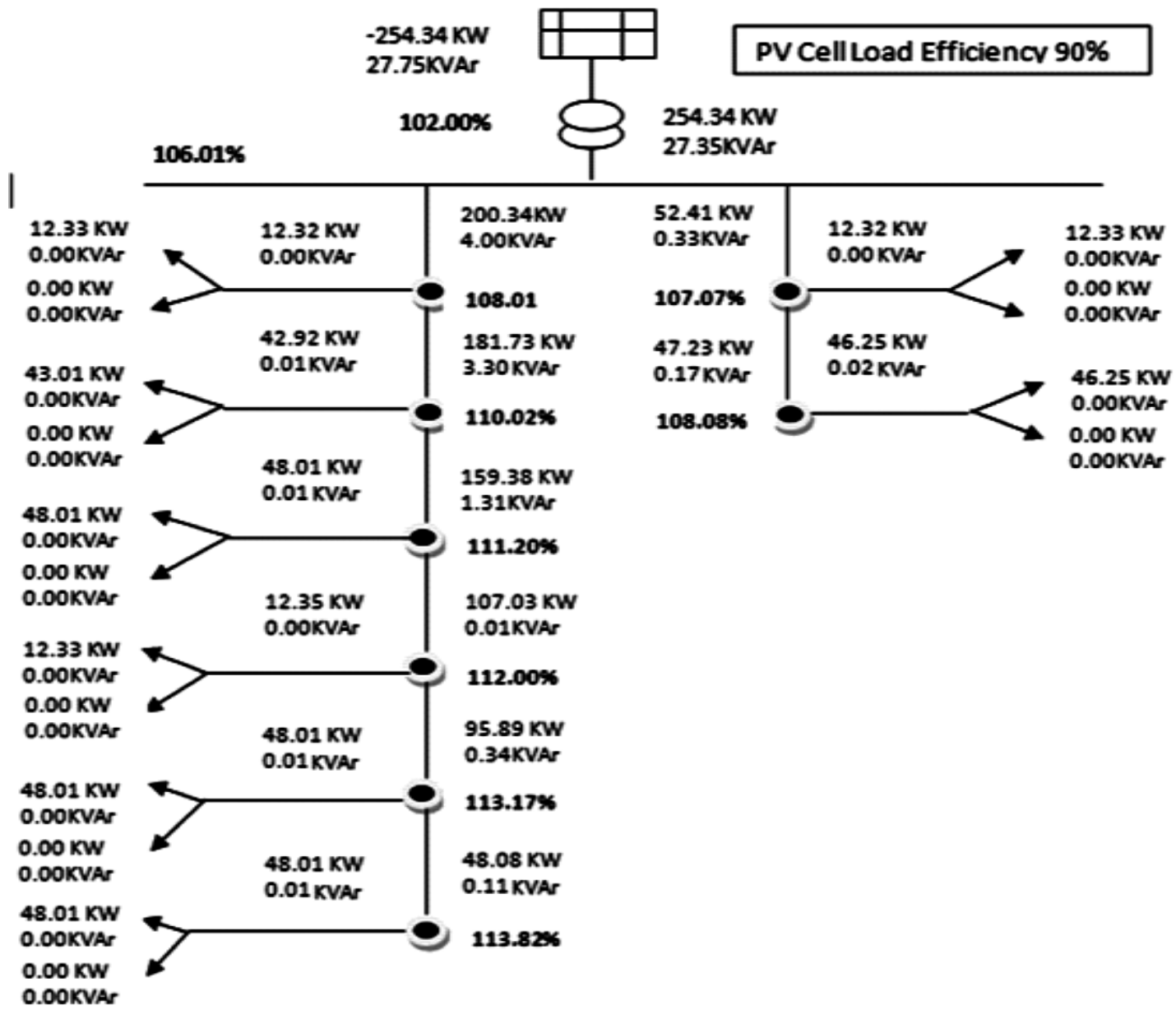

Figure 21. Single line diagram with 90\% load efficiency. 
U/Un [\%]

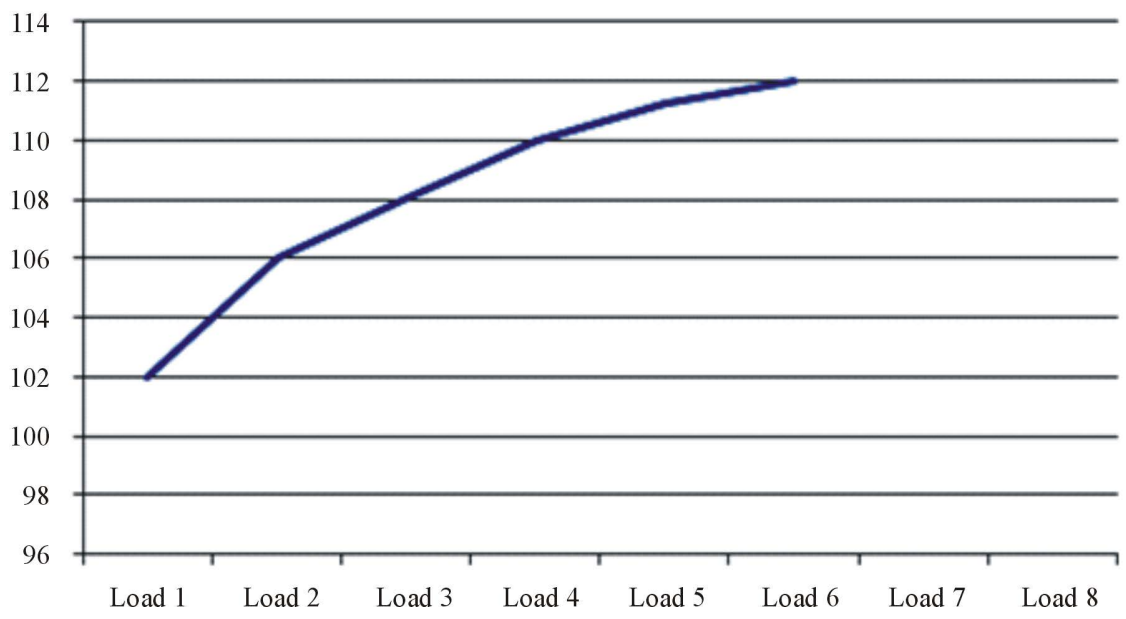

Figure 22. Loads efficiency with 90\% PV efficiency.

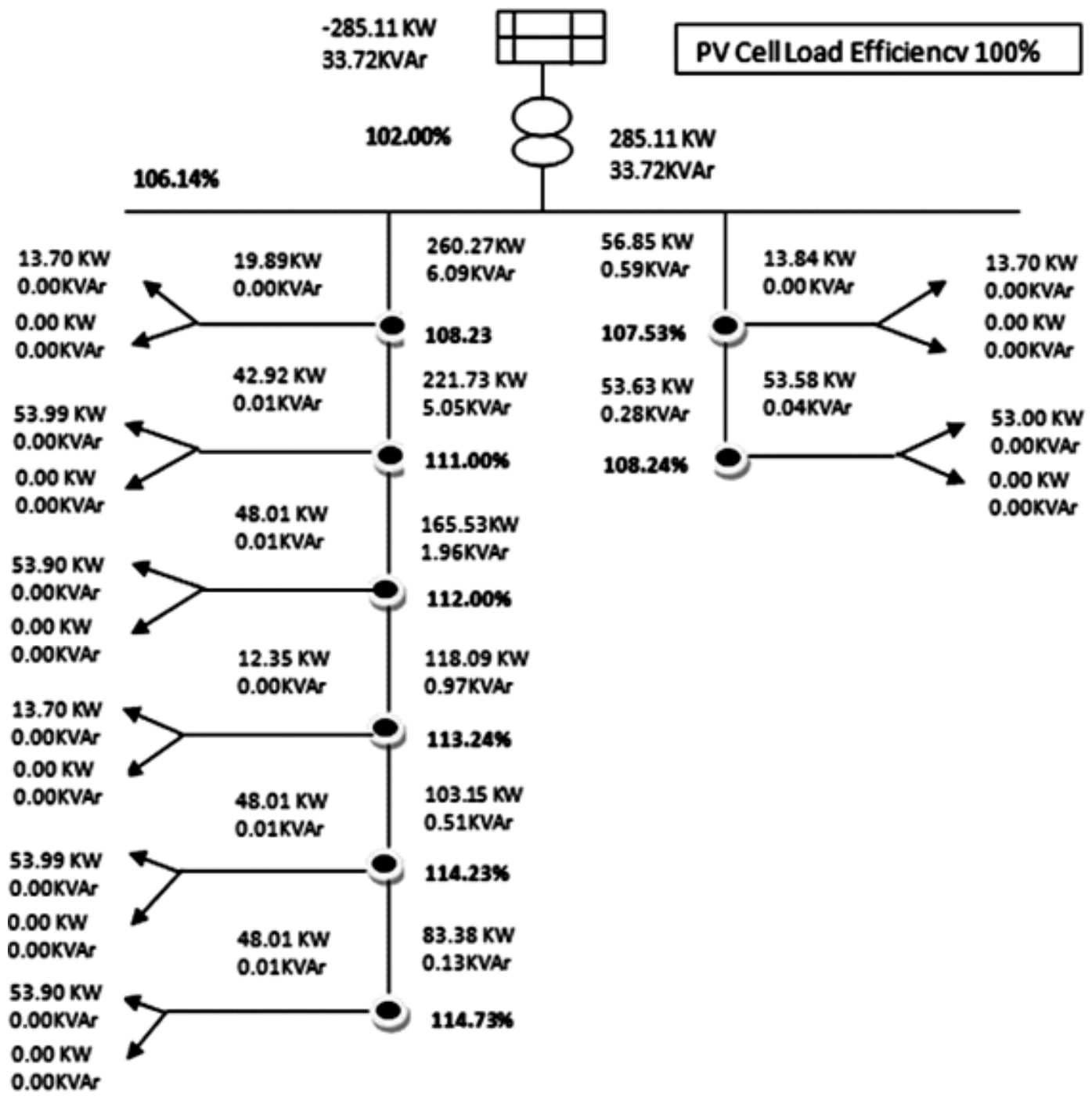

Figure 23. Single line diagram with $100 \%$ load efficiency. 
U/Un [\%]

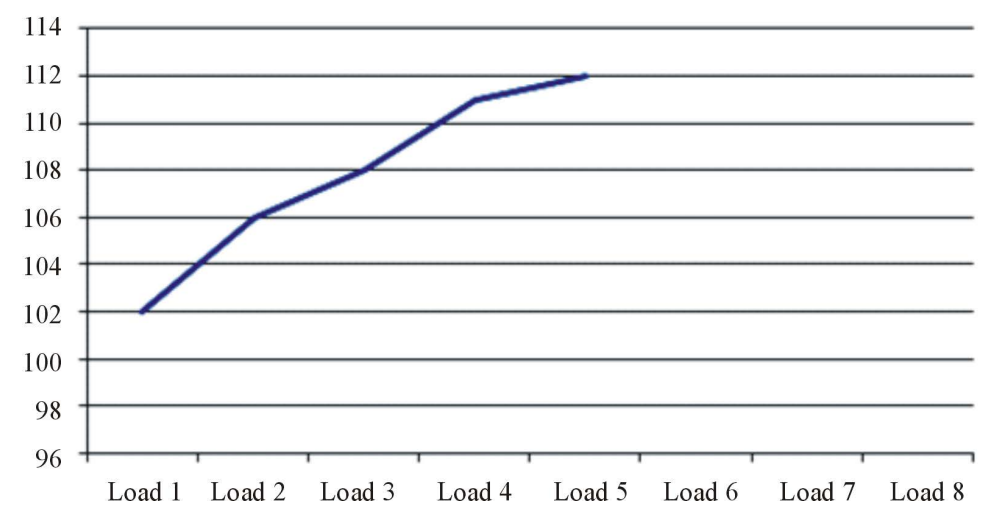

Figure 24. Loads efficiency with $100 \%$ PV efficiency.

\section{Conclusions}

In this research paper, sixteen load points have been selected and these load points were supported by Microgrid. Microgrid uses alternative power systems to support these load points such as solar power, wind power etc. In this research work solar power was selected as an alternative energy source. After calculating harmonics and load efficiency, it can be concluded that when PV load efficiency increases gradually, the load supporting points decrease and loss increases and reaches out of limit. In the future we can use wind power and also fuel cell power to support Microgrid system. Microgrid technology can control renewable resources to affect changes in the grid's operating conditions and can provide additional benefits as distributed generation assets or when installed at the transmission level. Distributed generation can support weak grids, add grid voltage and improve power quality.

The demand of energy generation worldwide grows rapidly, because energy generation is low but energy consumption is on a high rate. Electricity companies cannot satisfy consumers with this electricity generation rate for population and must use renewable energy system by using Microgrid technology.

Microgrid system should be deployed in Pakistan as well as in other developing countries. Pakistan has taken no steps to adopt Microgrid system with its prime role in energy system. Integration of renewable energy system in Microgrid has been proposed in this paper. If this system properly developed and implemented, it would make it much easier to adopt emerging technologies and improve economies conditions. If Microgrid system implemented in Pakistan, it would support the green energy and sustainable energy program in Pakistan. Microgrid system would reduce stress on the transmission and the distribution systems which is currently overloaded with a decaying infrastructure. This system would overcome the current energy crisis.

\section{References}

[1] Piwko, R. (2012) Grid Integration of Large-Capacity Renewable Energy Sources and Use of Large-Capacity Electrical Energy Storage. White Paper, IEC.

[2] Farret, F.A. and Simoes, M.G. (2006) Integration of Alternative Sources of Energy. John Wiley \& Sons, Hoboken.

[3] Mehrotra, P. (2011) Nanotechnology Applications in Energy Sector. Reinste Nano Ventures Nano Science and Technology.

[4] Vader, N.V. and Bhadang, M.V. (2010) Smart Grid with Renewable Energy. Renewable Research Journal. http://rexjournal.org.managewebsiteportal.com/files/documents/System-Integration-Smart-Grid-with-Renewable-Energ y---Mrs.-N.-V.-Vader.pdf

[5] Keyhani, A., Marwal, M.N. and Dai, M. (2010) Integration of Green and Renewable Energy in Electric Power Systems. John Wiley and Sons, Hoboken.

[6] Siril, P.F. (2003) Nanotechnology and Its Application in Renewable Energy. Science, 300, 1127.

[7] Farret, F.A. and Simoes, M.G. (2006) Integration of Alternative Energy Sources of Energy. John Wiley \& Sons, Hoboken.

[8] DOE’s Office of Energy Efficiency and Renewable Energy (2004) Solar Energy Technologies Program Multi-Year Technical Plan 2003-2007. 
Scientific Research Publishing (SCIRP) is one of the largest Open Access journal publishers. It is currently publishing more than 200 open access, online, peer-reviewed journals covering a wide range of academic disciplines. SCIRP serves the worldwide academic communities and contributes to the progress and application of science with its publication.

Other selected journals from SCIRP are listed as below. Submit your manuscript to us via either submit@scirp.org or Online Submission Portal.
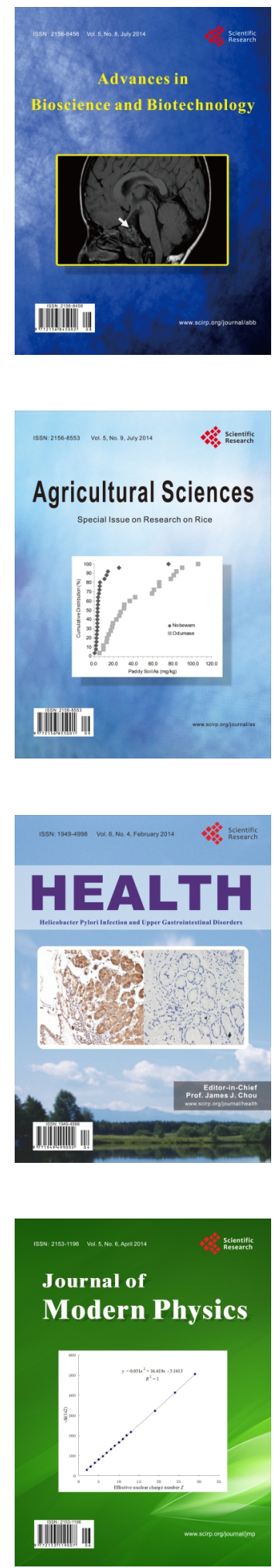
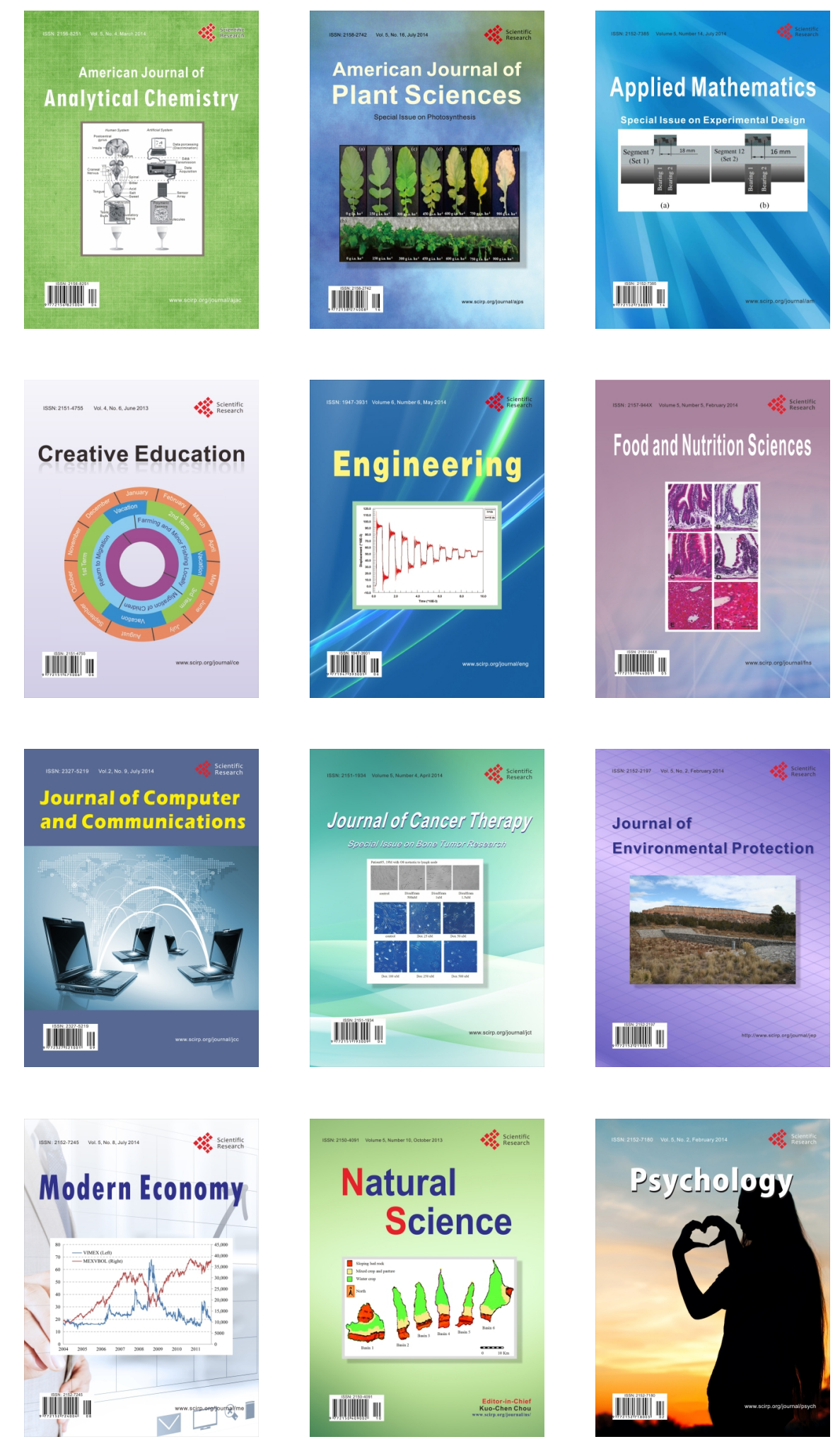